\title{
Effect of Thermal Exposure Simulating Vapor Deposition on the Impact Behavior of Additively Manufactured AlSi10Mg Alloy
}

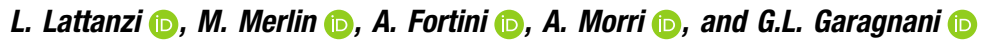 \\ Submitted: 13 May 2021 / Revised: 21 September 2021 / Accepted: 29 October 2021 / Published online: 19 November 2021
}

\begin{abstract}
The present work focuses on the evolution of hardness and impact toughness after thermal exposure at high temperatures of the AISi10Mg alloy produced by selective laser melting. The thermal exposure simulated the vapor deposition of coatings on aluminum alloys. The aim is to assess the possibility of combining the ageing step of heat treatments and the deposition treatment. The alloy was aged at 160 and $180{ }^{\circ} \mathrm{C}$ for up to 4 hours, both directly and after an innovative rapid solution treatment. Direct ageing had no significant effects on the microstructure, showing an almost constant hardness trend. These results accord with the impact properties, which showed a negligible difference in the impact toughness of the direct aged and the as-built samples. The same ageing treatments performed after rapid solution treatment induced age hardening in the alloy. The hardness values were lower by $38 \%$ than those of the directly aged samples. The innovative solution treatment positively affected impact toughness, which increased by $185 \%$ compared to the directly aged material. These results highlight that the ageing step can be integrated with the vapor deposition process. Moreover, the heat treatment is suitable for components requiring high impact strength after coating.
\end{abstract}

Keywords aluminum, additive manufacturing, heat treatment, mechanical testing

\section{Introduction}

Additive manufacturing (AM) processes have been gaining more and more light in recent years due to their flexible and versatile production, and the selective laser melting (SLM) of Al-Si-Mg systems have been extensively investigated (Ref 14). In particular, AlSi10Mg alloys are of interest thanks to their excellent processability and broad applicability in automotive structural components. The microstructure of AlSi10Mg alloys produced by SLM consists of supersaturated primary Al cells decorated by a network of eutectic Si. These unique features are related to high cooling rates and thermal gradients. The presence of fine $\mathrm{Si}$ and $\mathrm{Mg}$ precipitates in the $\mathrm{Al}$ matrix is reflected by appealing mechanical properties (Ref 1, 5-7). Drawbacks are linked to production defects and the instability of microstructure, and the exposure at a high temperature can be deleterious, leading to coarsening of $\mathrm{Si}$ particles and

L. Lattanzi, Department of Engineering, University of Ferrara, Via Saragat 1, 44122 Ferrara, Italy; and Department of Materials and Manufacturing, School of Engineering, Jönköping University, Gjuterigatan 5, Box 1026, 55110 Jönköping, Sweden; M. Merlin, A. Fortini, and G.L. Garagnani, Department of Engineering, University of Ferrara, Via Saragat 1, 44122 Ferrara, Italy; and A. Morri, Department of Industrial Engineering, Alma Mater and Studiorum, University of Bologna, Viale Risorgimento 4, 40136 Bologna, Italy. Contact e-mails: lucia.lattanzi@ju.se, mattia.merlin@unife.it, annalisa.fortini@unife.it, alessandro.morri4@unibo.it, and gian.luca. garagnani@unife.it. precipitates with parallel depletion of matrix saturation. The obstacles come with heat treatments and, in general, industrial processes that involve exposure at high temperatures, like the deposition of coatings. Protective and reinforcing coatings are often required for automotive and aerospace applications of AlSi10Mg components, but the sensitivity to temperature of the substrate is a limiting factor in deposition processes. To the knowledge of the authors, studies focused on the effect of vapor deposition (VD) treatments on Al-based alloys are not available, and the literature investigated the thermal evolution of additively manufactured (AMed) materials mainly in terms of heat treatments. Prashanth et al. (Ref 4) investigated annealing treatments on AlSi12 alloys at temperatures in the $200-450{ }^{\circ} \mathrm{C}$ range for $6 \mathrm{~h}$. The microstructure variation was significant at the expense of $\mathrm{Si}$ both in the eutectic network and in the supersaturated $\alpha$-Al matrix. This phenomenon led to a variation in the mechanical properties of the material. The yield strength (YS) decreased from 260 to $95 \mathrm{MPa}$ for the coarsest microstructure, while the fracture strain increases from 3 to $15 \%$. Yang et al. (Ref 8 ) also focused on annealing treatments of AlSi10 alloys and reported that the temperature increase led to a sequential change as the material progressively approaches its equilibrium. Si dissolution, precipitation, collapsing of the cellular structure, and microstructure ripening were the main phenomena. Fiocchi et al. (Ref 9) focused on low-temperature annealing treatments for AlSi10Mg alloys. The authors stated that the SLM process requires specific post-building thermal treatments that can be performed at temperatures lower than the conventional ones to reduce industrial production costs.

For some studies, the starting point was the well-known practice for cast AlSi10 alloys. Li et al. (Ref 10) applied the standard T6 heat treatment, which consists of high-temperature solution heat treatment (SHT) followed by artificial ageing (AA). During SHT, Si atoms precipitated from the supersaturated $\alpha-\mathrm{Al}$ matrix to form $\mathrm{Si}$ particles, and their size depends on 
the temperature. The Si particles were further coarsened by AA, and this phenomenon significantly affected mechanical strength, with a beneficial effect on the elongation. Fousova et al. (Ref 11) compared the classical T6 with annealing treatments. Takata et al. (Ref 12) and Maamoun et al. (Ref 13) focused on the SHT. In the AlSi10Mg alloy held at an elevated temperature, the Si phase was found to finely precipitate within the columnar $\alpha$-Al phase and coarsening of the eutectic Si particles occurred. Zhou et al. (Ref 14) studied the T6 heat treatment on the AlSil0 alloy, varying the time of SHT and AA. The AA at $160{ }^{\circ} \mathrm{C}$ led to the formation of metastable $\beta-\mathrm{Mg}_{2} \mathrm{Si}$ precipitates. The GP zones and $\beta^{\prime \prime}$ were identified after $10 \mathrm{~h}$ of AA, the peak ageing, and $\beta^{\prime \prime}$ existed up to $24 \mathrm{~h}$ of AA. Casati et al. (Ref 15) compared the effect of the T6 heat treatment on AlSi10 alloys processed with cold- and hot-build platforms. Hot-platform processing led to a significant loss of the ageing response with a concurrent drop of mechanical properties. The authors supposed that the holding times spent at high temperatures during processing could induce an overaged temper in the material. The standard T6 heat treatment resulted in the lowest achievable strength and thus inappropriate for the SLMprocessed AlSi10 alloys when high strength is required. Zhuo et al. (Ref 16) explored two different regimes, annealing at 300 ${ }^{\circ} \mathrm{C}$ for $2 \mathrm{~h}$ followed by water quench, and T6 treatment (SHT at $535^{\circ} \mathrm{C}$ for $1 \mathrm{~h}$, water quench, AA at $190{ }^{\circ} \mathrm{C}$ for $10 \mathrm{~h}$ ). The first regime effectively reduced residual stresses, while the second regime affected the tensile properties. Van Cauwenbergh et al. (Ref 17) studied direct ageing at $170{ }^{\circ} \mathrm{C}$, among other stressrelieving treatments, on AlSi7 and AlSi10 alloys. The authors reported that the strength was maintained at the expense of ductility due to the fine precipitation of $\mathrm{Si}$, and thus direct ageing is suitable for high strength applications.

Low-temperature treatments have been assessed for additively manufactured Al-Si systems (Ref 9, 11, 17, 18). In particular, Fiocchi et al. (Ref 18) investigated tailored treatments for hot-platform produced Al-10Si alloys compared to a T5-like treatment at $170{ }^{\circ} \mathrm{C}$. The authors reported that the T5like ageing at $170{ }^{\circ} \mathrm{C}$ was able to slightly improve the mechanical resistance of the AlSi10Mg samples for short treatment durations, thanks to the precipitation of $\beta^{\prime \prime}$ from the supersaturated solid solution.

The literature survey shows that one critical aspect for the additively manufactured AlSil0Mg alloy is assessing how microstructure and mechanical properties could change during coating deposition processes that require prolonged thermal exposure above $160^{\circ} \mathrm{C}$. The target of the present work is to evaluate the possibility to combine the ageing treatment with VD treatments, generally performed at $160-180{ }^{\circ} \mathrm{C}$ for $4 \mathrm{~h}$ (Ref 19). The present work investigates how thermal cycles that simulate the VD processes affect the microstructure, hardness and Charpy impact properties, which have been little investigated to date (Ref 20-24).

\section{Experimental Procedure}

\subsection{Production of Samples and Material Characterization in the As-Built Condition}

The samples were produced using SLM powder bed technology with an SLM ${ }^{\circledR} 500$ system (SLM Solutions, Lübeck, Germany) by the industrial partner BeamIt (Fornovo di Taro,
Italy). The production parameters were selected following the study by Bagherifad et al. (Ref 25). For the production of samples, which took about $30 \mathrm{~h}$, the building platform was maintained at $150{ }^{\circ} \mathrm{C}$. Two different geometries were produced, as represented in Figure 1. The disks (Fig. 1a) were used to evaluate density, microstructure and hardness, while the parallelepipeds (Fig. 1b) were used for Charpy impact tests. The chemical composition of disks and Charpy samples, evaluated by glow-discharge optical emission spectrometry, is reported in Table 1 . Specimens to investigate the as-built microstructure in the vertical and horizontal building directions were prepared with standard metallographic methods and observed with a DMI8 A (Leica Microsystems, Wetzlar, Germany) light optical microscope.

The density was measured using the hydrostatic weighing method on three disks in the as-built condition. The method consists of weighing the samples in air and distilled water through a Mettler Toledo AE240 (Mettler Toledo, Columbus, USA) analytical digital balance (with a resolution of $0.1 \mathrm{mg}$ ). Differential scanning calorimetry (DSC) was performed with a DSC Q 2000 (TA Instruments, New Castle-Delaware, USA) on a $10 \mathrm{mg}$ sample between 0 and $400{ }^{\circ} \mathrm{C}$ with a rate of $5^{\circ} \mathrm{C} / \mathrm{min}$ for heating ramps.

\subsection{Deposition-Simulating Treatments}

The samples were investigated in different conditions: asbuilt at the end of the $30 \mathrm{~h}$ production, after direct artificial ageing (T5), and after an innovative solution treatment followed by artificial ageing (T6-like). The artificial ageing treatment, either direct or after solution treatment, simulates the thermal exposure during the VD treatments, either chemical or physical. Table 2 shows the parameters employed for the performed deposition-simulating treatments. More details about the heat-treatment parameters, and their influence on both the microstructure and mechanical behaviour of the alloy, will be presented in future work. The rest of the article uses heattreatment terminology and acronyms as a text alternative to "deposition-simulating treatments."

The evolution of mechanical properties with the assessed thermal histories was checked by Brinell hardness tests performed with an applied load of $62.5 \mathrm{kgf}$ and a spherical indenter with a diameter of $2.5 \mathrm{~mm}$ (HBW10) on an ErnstCisam AT130 (Ernst-Cisam, Induno Olona, Italy) hardness tester. Microstructural investigations were carried out on

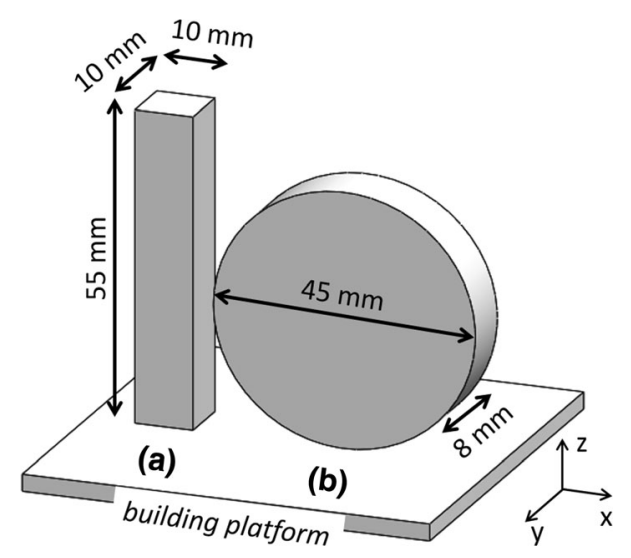

Fig. 1 Geometry and dimensions of the samples: (a) parallelepiped and (b) disc 
Table 1 Chemical composition (wt.\%) of the samples, compared to the ISO 17615-07 standard

\begin{tabular}{lllllr}
\hline Material & \multicolumn{1}{c}{$\mathbf{S i}$} & $\mathbf{M g}$ & $\mathbf{F e}$ & $\mathbf{C u}$ & $\mathbf{T i}$ \\
\hline Disc & 9.75 & 0.30 & 0.13 & & $\mathbf{A l}$ \\
Charpy specimen & 9.93 & 0.28 & 0.22 & $\ldots$ & 0.02 \\
ISO 17615 & $9.00-11.00$ & $0.25-0.45$ & $<0.45$ & $<0.08$ & $\mathrm{Bal}$ \\
\hline
\end{tabular}

Table 2 Parameters of the deposition-simulating treatments

\begin{tabular}{|c|c|c|c|}
\hline Deposition-simulating treatment & Solution heat treatment & Quench & Artificial ageing \\
\hline T5 & $\ldots$ & $\cdots$ & $160^{\circ} \mathrm{C}, 1-4 \mathrm{~h}$ \\
\hline T6-like & $510{ }^{\circ} \mathrm{C}, 10$ minutes & Water & $\begin{array}{l}180^{\circ} \mathrm{C}, 1-4 \mathrm{~h} \\
160^{\circ} \mathrm{C}, 1-4 \mathrm{~h} \\
180^{\circ} \mathrm{C}, 1-4 \mathrm{~h}\end{array}$ \\
\hline
\end{tabular}

metallographic sections of the disks in each heat-treated condition by a Zeiss EVO MA 15 (Zeiss, Oberkochen, Germany) scanning electron microscope.

Moreover, according to standard but secret parameters, an industrial 4-h diamond-like carbon (DLC) physical VD treatment was performed by the industrial partner STS Group (Cellatica, Italy) on one disk in the as-built condition in order to check and compare its hardness with the material properties in the simulated T5 heat-treatment condition. It was verified that the artificial ageing treatment performed for $4 \mathrm{~h}$ at $160^{\circ} \mathrm{C}$ could simulate the VD treatment, which led to $124 \pm 2$ HBW10.

\subsection{Charpy Impact Tests}

Parallelepipeds were machined to obtain the V-notch samples prescribed by the ISO 148-1 standard (Fig. 2a). Charpy impact tests were performed at room temperature on three samples for the following conditions: as-built, T5 after $4 \mathrm{~h}$ and T6-like after $4 \mathrm{~h}$. A CEAST (Ceast Instron, Pianezza, Italy) instrumented pendulum with available energy of $50 \mathrm{~J}$ was used, and the force-displacement curves were calculated according to the ISO 14556:2015 standard. Data were recorded by the CEAST DAS $64 \mathrm{~K}$ during impact. Raw data acquired during the impact tests were analyzed using a tailored Matlab $\AA$ code. Five significant parameters (Fig. 2b) were calculated from the force-displacement curves: the peak force $(\mathrm{Pf})$ is the maximum force value recorded during the test; the peak displacement $(\mathrm{Pd})$ is the displacement relative to the peak force; the total energy (Etot) is the amount of energy absorbed by the specimen and calculated as the integral under the load-displacement curve; the initiation energy (Ei) is the amount of energy absorbed at the peak force; the propagation energy (Ep) is the amount of energy absorbed from the peak force to the end of the test. The fracture surfaces and profiles of fractured Charpy specimens were also investigated by a Zeiss EVO MA 15 scanning electron microscope.

\section{Results}

\subsection{Characterization of the As-Built Material}

The microstructure of the as-built material (Fig. 3a) presented the typical semi-circular sections of melt pools on the $x-$
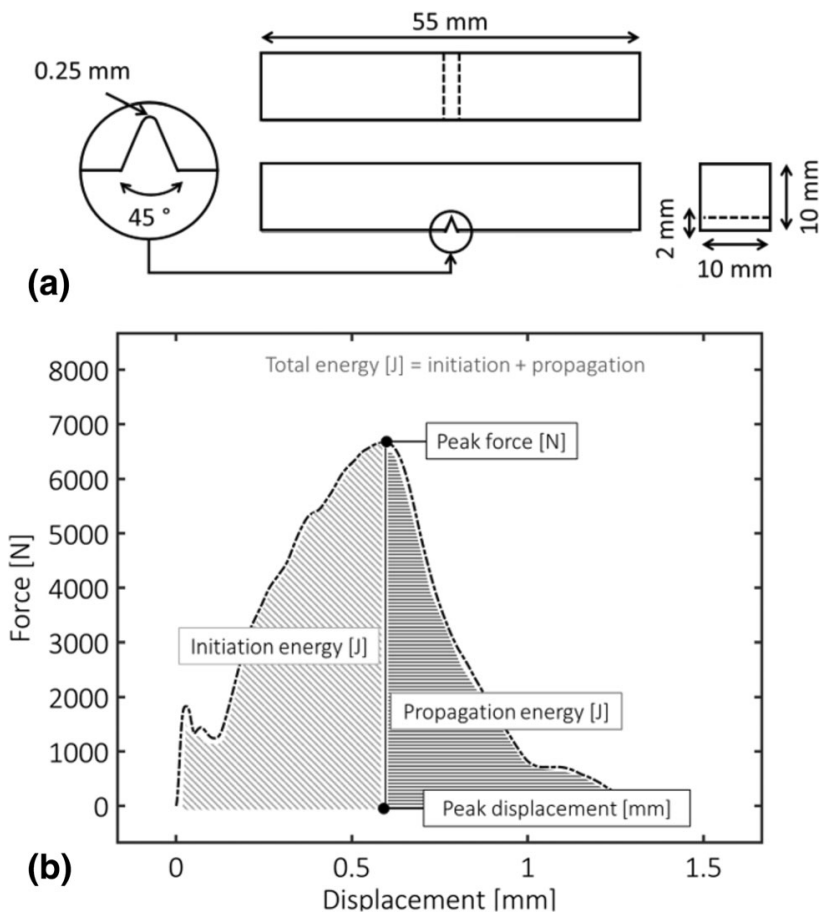

Fig. 2 (a) Dimensions of the V-notch Charpy specimen according to the ISO 148-1 standard; (b) force-displacement curve and related parameters

$z$ and $y-z$ sections. The scan strategy was evident on the $x-y$ section (Fig. 3b), with $67^{\circ}$ of misalignment between subsequent layers. The contour strategy was also evident at the edge of the samples (Fig. 3a).

The density of the as-built material varied slightly along the $z$-axis from $2.652 \pm 0.001 \mathrm{~g} / \mathrm{cm}^{3}(z<45 \mathrm{~mm})$ to $2.650 \pm$ $0.001 \mathrm{~g} / \mathrm{cm}^{3}(z>45 \mathrm{~mm})$. The average value of $2.651 \mathrm{~g} / \mathrm{cm}^{3}$ corresponds to $99 \%$ of the conventionally cast alloy density, which is $2.680 \mathrm{~g} / \mathrm{cm}^{3}$.

The heating ramp of the DSC thermogram of the as-built material is reported in Fig. 3(c), and two exothermic peaks were evident. The first peak at $239.8{ }^{\circ} \mathrm{C}$ subtends a transformation enthalpy of $7.07 \mathrm{~J} / \mathrm{g}$ and the second peak at $307.7^{\circ} \mathrm{C}$, slightly asymmetrical, subtends a transformation enthalpy of $5.55 \mathrm{~J} / \mathrm{g}$. 

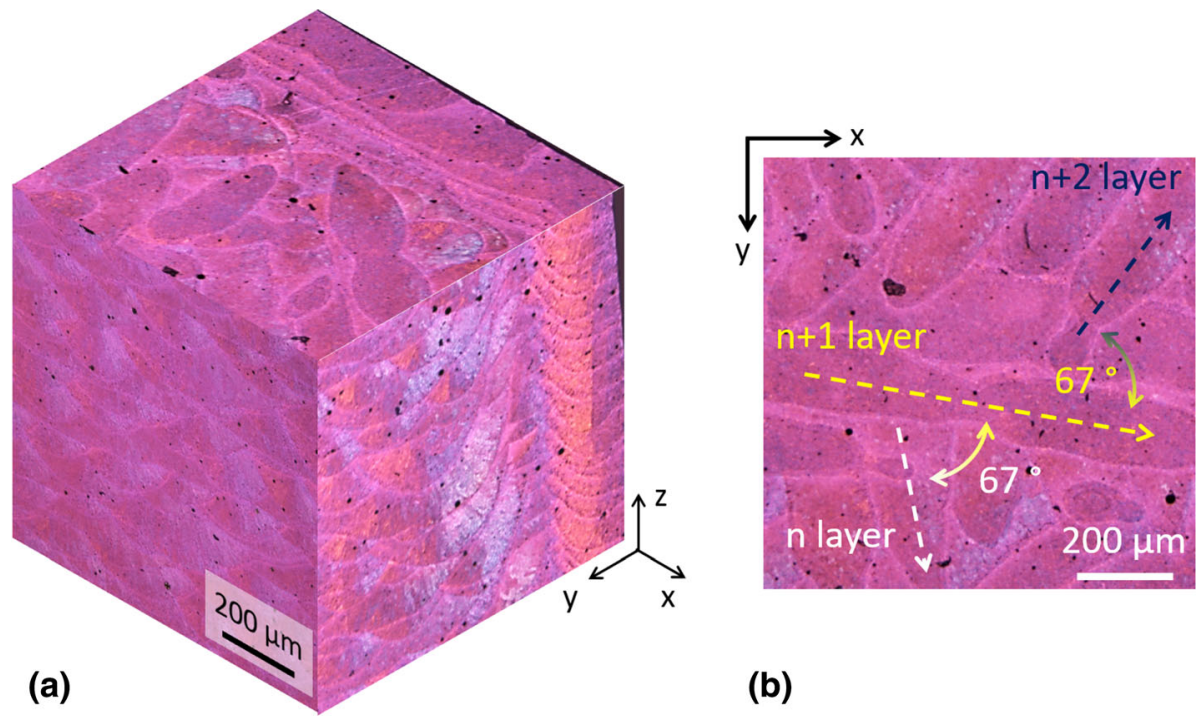

(b)

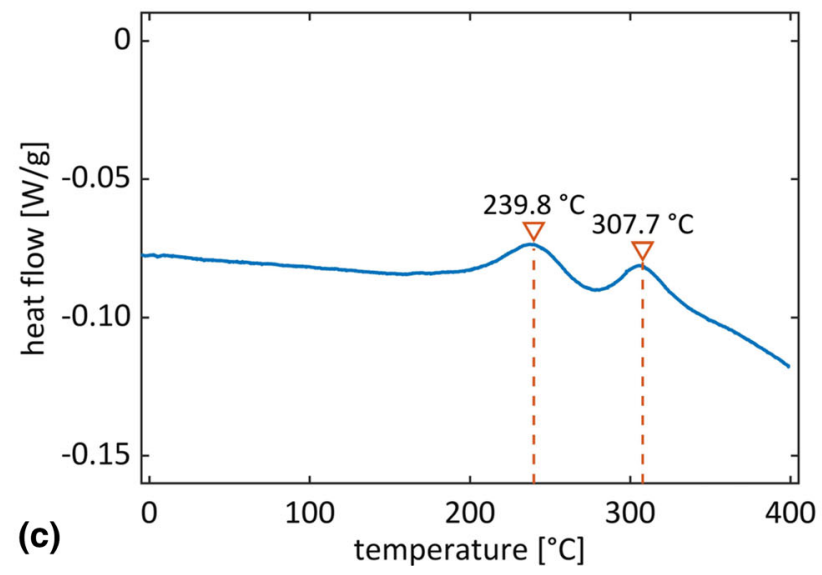

Fig. 3 As-built material: (a) microstructure of the different sections; (b) scan strategy in the $x-y$ section; (c) DSC thermogram, heating ramp

\subsection{Deposition-Simulating Treatments}

The heat treatments performed in the present work were designed to experimentally simulate the exposure of the alloy at high temperatures during a typical VD treatment and monitor the material evolution. The T5 condition represents the direct VD treatment after SLM production. The T6 treatment is an alternate route and can be industrially reproduced with an innovative rapid SHT before the VD process.

Figure 4 depicts the hardness trends during $4 \mathrm{~h}$ of thermal exposure. Direct ageing (Fig. 4a) led to a slight reduction in hardness for both the investigated temperatures. The exposure at $160{ }^{\circ} \mathrm{C}$ reduced hardness to $\sim 120 \mathrm{HBW} 10$, in line with the hardness measurements after the industrial VD treatment (Sect. 2.2), and maintained a constant trend. The exposure at $180{ }^{\circ} \mathrm{C}$ determined an initial decrease to $\sim 120 \mathrm{HBW} 10$ followed by a linear decrease to $\sim 115 \mathrm{HBW} 10$. As expected, the SHT decreased hardness to $\sim 69 \mathrm{HBW} 10$ (Fig. 4b). The subsequent thermal exposure at $180{ }^{\circ} \mathrm{C}$ determined a slight increase in hardness, to a maximum of $\sim 75$ HBW10 between 3 and $4 \mathrm{~h}$. The artificial ageing at $160{ }^{\circ} \mathrm{C}$ determined a more significant increase after $4 \mathrm{~h}$, up to $\sim 90 \mathrm{HBW} 10$. The general trend is similar to that at $180{ }^{\circ} \mathrm{C}$ (Fig. $4 \mathrm{~b}$ ). Nevertheless, the hardness values after the $\mathrm{T} 6$ heat treatment did not increase back to the as-built values. The evolution of the microstructure at different stages is depicted in Figure 5. In the as-built material (Fig. 5a), a fine network of eutectic Si limited primary $\alpha$-Al cells. Direct ageing at $180{ }^{\circ} \mathrm{C}$ for $4 \mathrm{~h}$ (Fig. 5b) did not significantly change the microstructure, as the primary cells were still visible, and the eutectic network appeared only slightly fragmented in some areas. Significant was the effect of the high-temperature SHT (Fig. 5c), despite its brevity. The cellular microstructure with the eutectic Si network surrounding $\alpha$-Al evolved into a microstructure of Si particles embedded in the $\alpha$-Al matrix. The boundaries of melt pools were not detected either. The subsequent thermal exposure at $180^{\circ} \mathrm{C}$ for $4 \mathrm{~h}$ (Fig. 5d) did not significantly alter the microstructure, characterized by $\mathrm{Si}$ particles in the $\alpha$-Al matrix. Similar observations are valid for the same ageing treatments at 160 ${ }^{\circ} \mathrm{C}$, which did not alter the initial microstructure significantly.

\subsection{Impact Properties}

Figure 6 depicts representative load-displacement curves recorded during Charpy impact tests. For the as-built material (Fig. 6a), the curve presented the Pf of $\sim 4.5 \mathrm{kN}$ and a total 


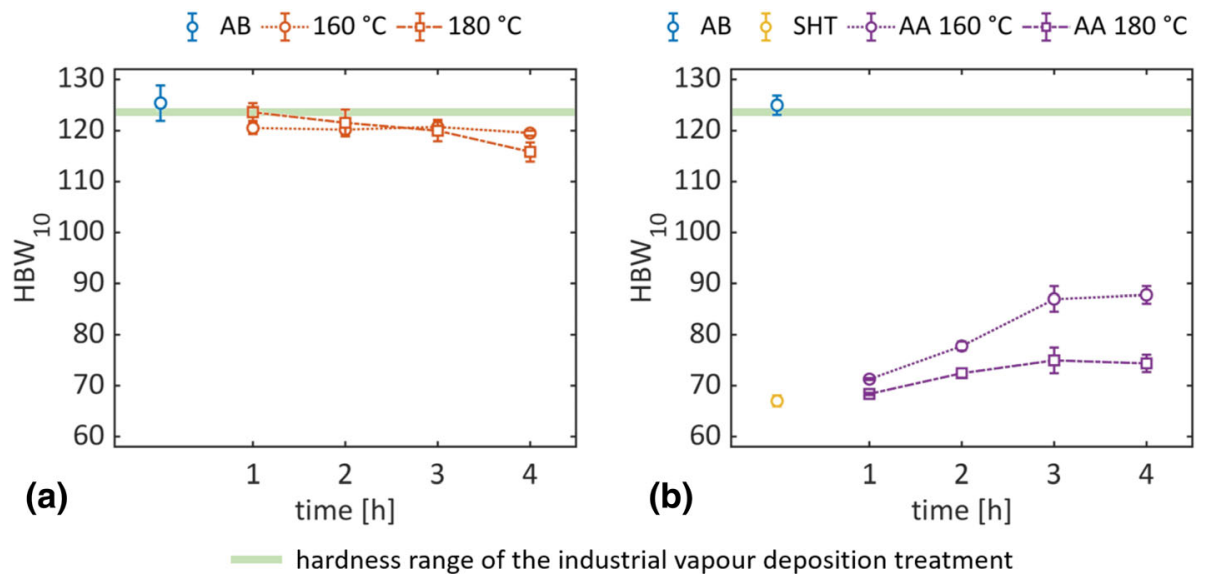

Fig. 4 Hardness values for 4 h: (a) T5 treatment; (b) T6-like treatment. The error bars represent the standard deviation. The trend lines are meant to guide the eye.
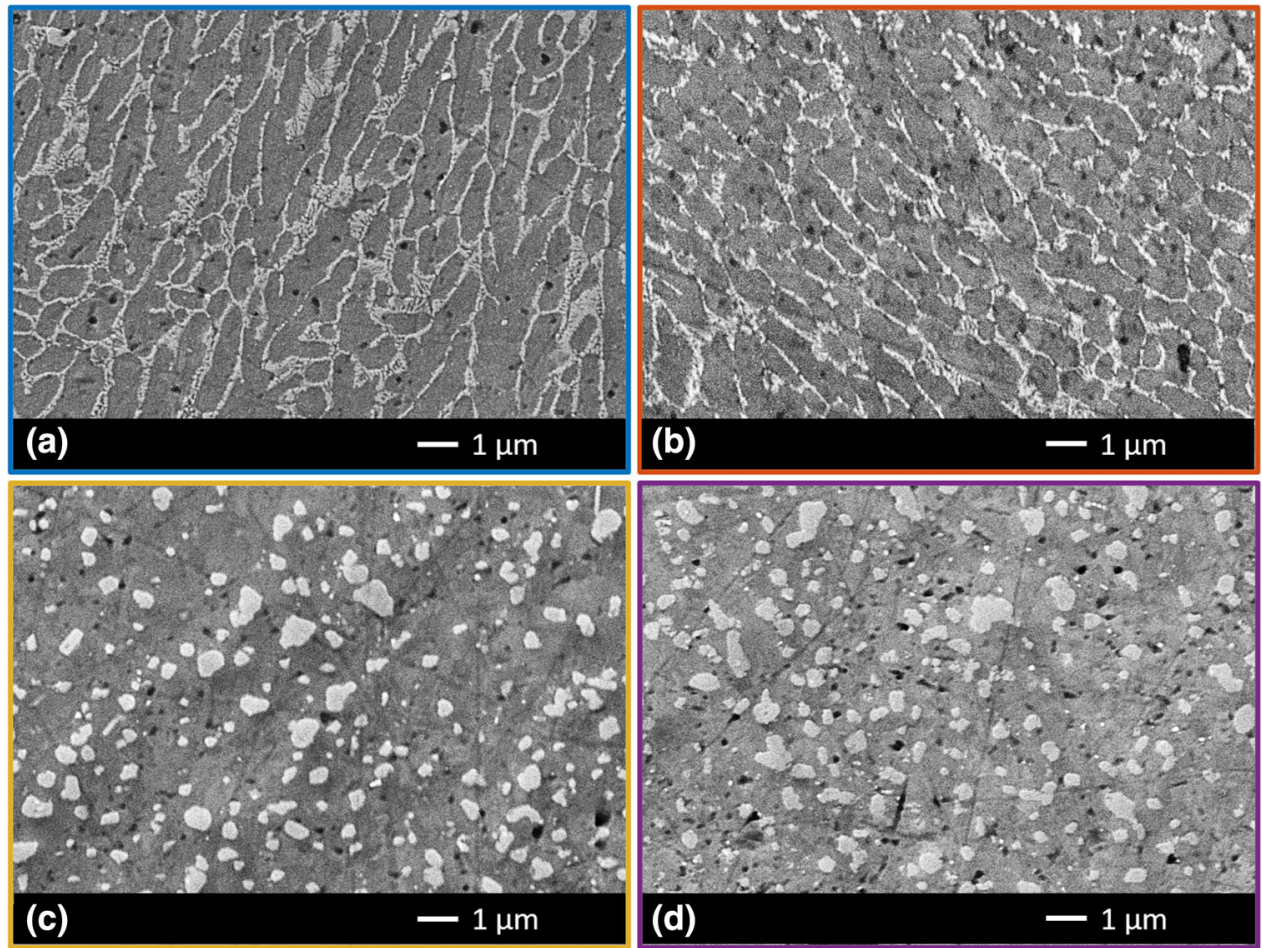

Fig. 5 Microstructure at different conditions: (a) as-built; (b) T5 at $180{ }^{\circ} \mathrm{C}$ after $4 \mathrm{~h}$; (c) SHT at $510{ }^{\circ} \mathrm{C}, 10$ minutes; (d) $\mathrm{T} 6$-like at $180{ }^{\circ} \mathrm{C}$ after $4 \mathrm{~h}$

displacement of $1.5 \mathrm{~mm}$. The initiation energy was $\sim 40 \%$ of the total absorbed energy, as listed in Table 3 . The T5 deposition-simulating treatments at 160 and $180{ }^{\circ} \mathrm{C}$ (Fig. 6b) did not alter the shape of the load-displacement curve, and the energy values remained similar to those for the as-built material (Table 3).

Different observations hold for the T6 treatments at 160 and $180{ }^{\circ} \mathrm{C}$ (Fig. 6c). The total absorbed energy increased to $\sim 6.3-$ $6.5 \mathrm{~J}$, three times the values obtained for as-built and T5 conditions. The Pf increased to $\sim 5 \mathrm{kN}$, and the peak displacement was shifted forward to $0.6 \mathrm{~mm}$. The initiation energy, listed in Table 3 , is about $30 \%$ of the total energy, so the ratio of energy contributes was also changed by the T6 treatments. Fracture surfaces and profiles after Charpy impact tests are presented in Figure 7. The fracture mainly followed the scan tracks in all the investigated conditions. This phenomenon was detectable in the as-built (Fig. 7a) and T5 (Fig. 7c) samples, and it agrees with the microstructural features observed in Fig. 5(a) and (b). A similar fracture surface was also observed for the T6 samples (Fig. 7e), although the melting pools were no longer evident on the polished surface. The fracture profiles in Fig. 7(b), (d) and (f) clarify that the fracture is mixed, presenting inter-layer, inter-track and trans-track segments regardless of the material condition. 

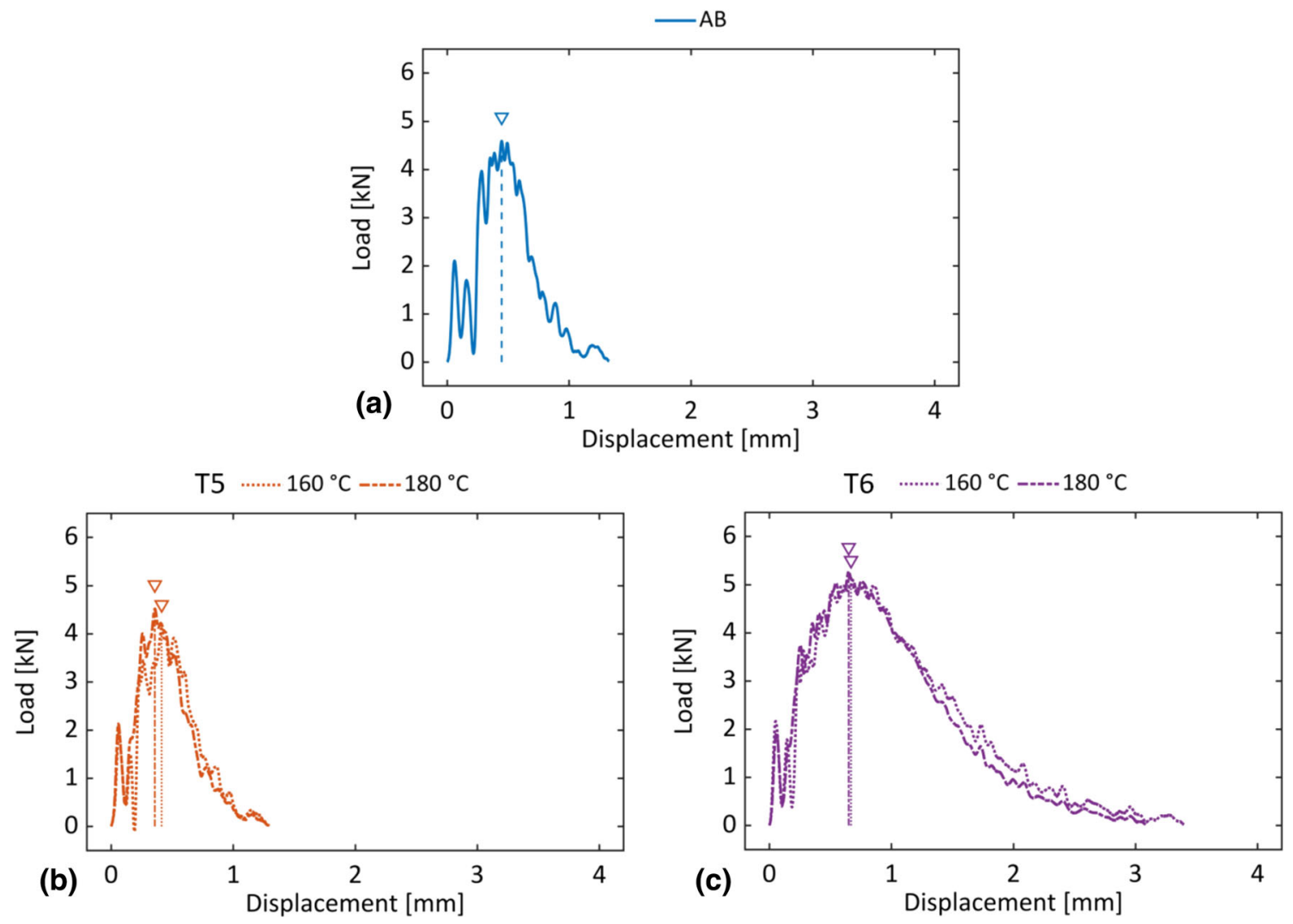

Fig. 6 Load-displacement curves in different conditions: (a) as-built; (b) T5 after 4 h; (c) T6-like after $4 \mathrm{~h}$

Table 3 Impact parameters calculated from the load-displacement curves: peak force (Pf), peak displacement (Pd), total energy (Etot), initiation energy (Ei), propagation energy (Ep)

\begin{tabular}{|c|c|c|c|c|c|}
\hline Condition & Pf, kN & Pd, mm & Etot, J & $\mathbf{E i}, \mathbf{J}$ & Ep, J \\
\hline $\mathrm{AB}$ & $4.53 \pm 1.6$ & $0.40 \pm 0.04$ & $2.23 \pm 0.20$ & $0.90 \pm 0.09$ & $1.33 \pm 0.20$ \\
\hline $\mathrm{T} 5-160{ }^{\circ} \mathrm{C}$ & $4.31 \pm 3.65$ & $0.42 \pm 0.01$ & $2.18 \pm 0.14$ & $0.93 \pm 0.10$ & $1.25 \pm 0.07$ \\
\hline $\mathrm{T} 5-180^{\circ} \mathrm{C}$ & $4.31 \pm 2.52$ & $0.41 \pm 0.04$ & $2.23 \pm 0.06$ & $0.88 \pm 0.04$ & $1.35 \pm 0.04$ \\
\hline T6-like $-160^{\circ} \mathrm{C}$ & $5.13 \pm 0.88$ & $0.62 \pm 0.06$ & $6.36 \pm 0.77$ & $1.98 \pm 0.25$ & $4.38 \pm 0.53$ \\
\hline T6-like- $180^{\circ} \mathrm{C}$ & $5.01 \pm 1.89$ & $0.66 \pm 0.01$ & $6.55 \pm 0.53$ & $2.06 \pm 0.07$ & $4.49 \pm 0.49$ \\
\hline
\end{tabular}

\section{Discussion}

\subsection{Characterization of the As-Built Material}

The density measures with a little standard deviation confirmed that the selected process parameters led to constant sound quality of the produced material. The microstructure is typical of the SLM production, with fine $\alpha$-Al cells surrounded by the eutectic network. The hardness of the as-built AMed material was $\sim 125 \mathrm{HBW} 10$, in line with the literature data (Ref $26,27)$, and thus twofold higher than the correspondent as-cast material, assessed of $63 \pm 2 \mathrm{HBW} 10$ by Girelli et al. (Ref 27). This significantly increased hardness, and consequently strength, was ascribed to both the fine cellular microstructure by Thijs et al. (Ref 28) and the supersaturated solid solution of $\mathrm{Si}$ in the $\alpha$-Al by Maeshima and Oh-ishi (Ref 29) that characterize the AMed material.

The data concerning the impact properties available in the literature (Ref 20-22) for as-built samples are not directly comparable with the present work because the production conditions, like the temperature of the building platform and the production duration, were not stated. Similar to what was observed for hardness, the impact properties in Table 3 are significantly higher than the results obtained by Girelli et al. (Ref 21) for the same alloy in the as-cast condition. They reported that the average total absorbed energy was $1.88 \mathrm{~J}, 44 \%$ absorbed during initiation and $56 \%$ during propagation. Although the absolute values are lower for the as-cast material, the percentage of initiation and propagation are comparable with the SLM alloy. Considering that the fracture mechanisms involved in the fracture of as-cast aluminum alloys are different from the same alloys processed by SLM, Girelli et al. (Ref 21) concluded that the propagation mechanisms involved in the ascast material absorb less energy than the mechanisms active in the SLM material. Also Kempen et al. (Ref 20) and Rakesh Ch et al. (Ref 22) reported a total absorbed energy in the range of 2.5-3 J for the as-cast material, 20\% lower than the SLM material, even though with no details about initiation and 

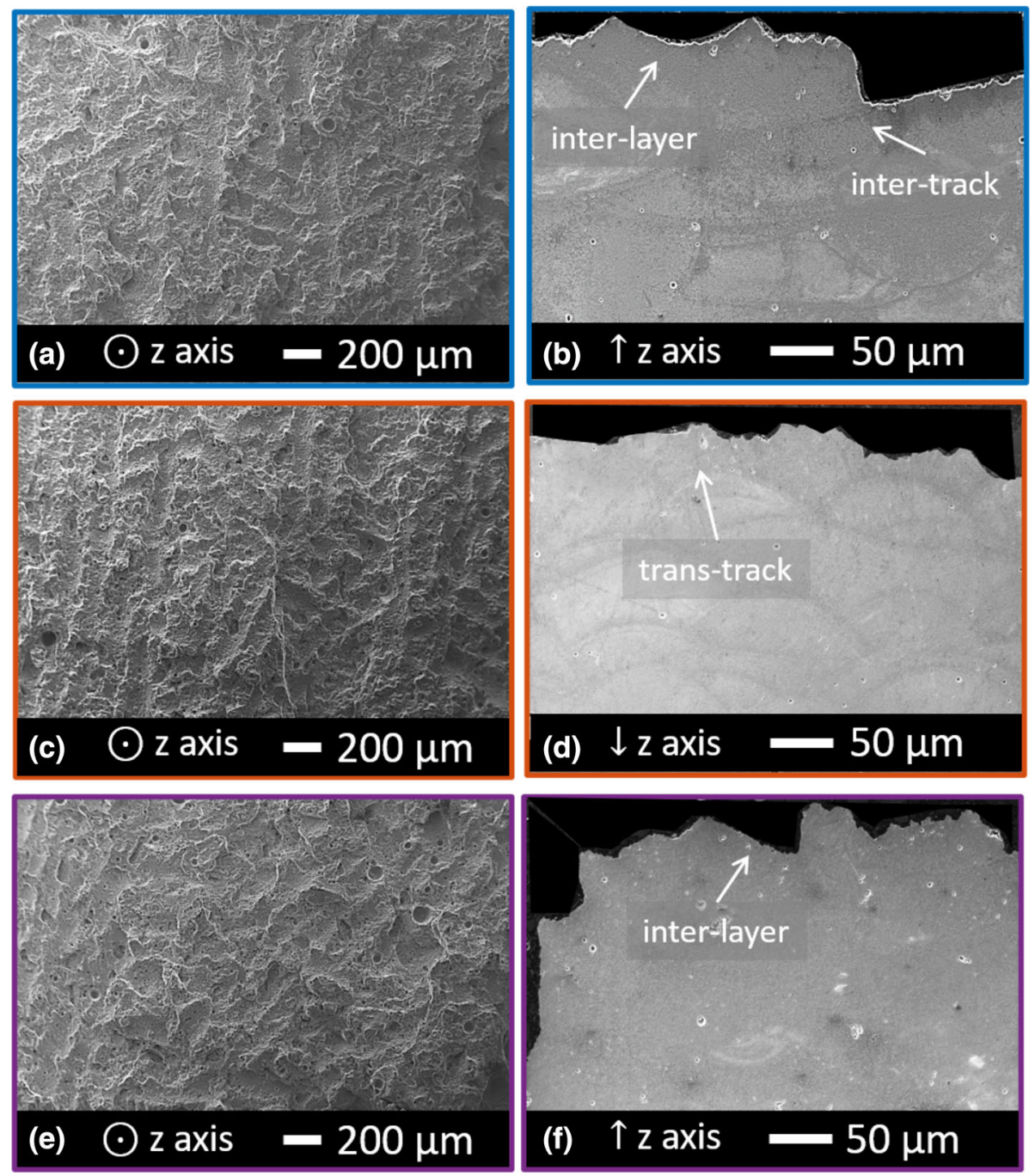

Fig. 7 Fracture surfaces and profiles after impact test: (a, b) as-built; (c, d) T5 at $180{ }^{\circ} \mathrm{C}$ after $4 \mathrm{~h}$; (e, f) T6-like at $180{ }^{\circ} \mathrm{C}$ after $4 \mathrm{~h}$

propagation contributions. The difference of data reported for the as-cast material can be ascribed to the casting method: Girelli et al. (Ref 21) used gravity casting while Kempen et al. (Ref 20) employed high-pressure die-casting, the latter improving the mechanical properties of the alloy compared to gravity casting. The casting method used by Rakesh Ch et al. (Ref 22) was not specified.

The DSC thermogram (Fig. 3b) clarified the reactions that occur during heating. According to the literature, the first peak at $239.8{ }^{\circ} \mathrm{C}$ was linked to the precipitation of the $\beta-\mathrm{Mg}_{2} \mathrm{Si}$ phase $(\operatorname{Ref} 9,30,31)$. It is also present in the conventionally cast alloy (Ref 9, 32, 33) within the same temperature range, which clarifies that the peak is independent of the production process. It is an intrinsic characteristic of the AlSi10Mg alloy. The second peak at $307.7^{\circ} \mathrm{C}$ was associated with the $\mathrm{Si}$ diffusion due to the supersaturation of the primary matrix in the SLM process. This peak, instead, was not detected in the cast alloy, and it is due to the high solidification rate typical of the SLM process.

Nevertheless, identifying these peaks is a debated topic since Marola et al. (Ref 34, 35) assigned the first peak at 160$250{ }^{\circ} \mathrm{C}$ to the $\mathrm{Si}$ precipitation and the second peak at 280 -
$340{ }^{\circ} \mathrm{C}$ to secondary intermetallic compounds like $\beta$ - $\mathrm{Mg}_{2} \mathrm{Si}$. The enthalpy values in the present work were lower than the values obtained by Fiocchi et al. (Ref 9) with a cold platform that reported 20.8 and $7.2 \mathrm{~J} / \mathrm{g}$, respectively. This difference is due to the use in the present work of the heated platform, which promoted $\beta-\mathrm{Mg}_{2} \mathrm{Si}$ precipitation and Si diffusion already during the production process. For this reason, the transformation energy was already partly consumed when the material was removed from the platform. Casati et al. (Ref 15) investigated the influence of the pre-heated platform at $160{ }^{\circ} \mathrm{C}$ on the AlSil0Mg alloy and obtained a flat DSC thermogram without prominent peaks. The absence of transformation peaks confirmed that the most of the precipitation occurred during production, and thus, reinforcing phases could not precipitate during artificial ageing. The DSC thermogram in the present work showed small transformation peaks, and it is due to the combination of a production time longer than $30 \mathrm{~h}$ and a temperature higher than $150{ }^{\circ} \mathrm{C}$, that led to the disappearance of transformation peaks. This observation enables to conclude that the material investigated in this work can present limited precipitation of $\beta-\mathrm{Mg}_{2} \mathrm{Si}$ after further thermal exposure. 


\subsection{Deposition-Simulating Treatments and Mechanical Properties}

Considering the hardness trends in Fig. 4(a) and the microstructure evolution in Fig. 5(b), the slight decrease in hardness during the $\mathrm{T} 5$ deposition-simulating treatments at 160 and $180{ }^{\circ} \mathrm{C}$ was due to a combination of slight distension of residual stresses and the over-ageing of the $\beta-\mathrm{Mg}_{2} \mathrm{Si}$ precipitated during the hot-platform production. This assumption is in line with results from Fiocchi et al. (Ref 18), which reported a decrease in residual stresses within the $24-48 \%$ range after 90 min at $170{ }^{\circ} \mathrm{C}$. The limited precipitation of $\beta-\mathrm{Mg}_{2} \mathrm{Si}$, supposed according to the DSC thermogram in Fig. 3(b), did not have a strengthening effect able to compensate for the hardness decrease due to the stress relief and the over-ageing during production. Casati et al. (Ref 15) also reported a slight loss in hardness on isothermal ageing at $160{ }^{\circ} \mathrm{C}$ of hot-platform produced samples and concluded that over-ageing effects occur during production, depending on printing time. Conversely, Fiocchi et al. (Ref 18), investigating a hot-platform produced material, reported a stable hardness evolution during T5 at 170 ${ }^{\circ} \mathrm{C}$. In the present work, for a material produced on a heated platform, the T5 treatment affected similarly to the stressrelieving treatments that have a limited impact on the mechanical properties. Also, the impact properties were not significantly altered than the as-built material, as evident in Fig. 6(b) and Table 3. The fracture behaviour was similar for both as-built (Fig. 7a, b) and T5 (Fig. 7c, d) materials, with evident influence by the scan tracks on the fracture surface. Rosenthal et al. (Ref 24) applied a modified T5 (AA at $200{ }^{\circ} \mathrm{C}$ for $2 \mathrm{~h}$ ) to an AlSi10Mg alloy produced by SLM and performed a non-instrumented Charpy impact test on samples built along the $z$-axis. The only data available is that their modified T5 halved the total absorbed energy compared to the as-built material. In the present study, the direct AA performed at lower temperatures, i.e., 160 and $180^{\circ} \mathrm{C}$, did not affect the absorbed energy compared to the as-built material.

About the T6-like deposition-simulating treatment, the innovative rapid SHT was enough to disrupt the eutectic network that contributes to the noticeable hardness in the asbuilt state. The diffusion and coalescence of silicon particles are evident in Fig. 5(c) and were maintained after AA at 160 and $180{ }^{\circ} \mathrm{C}$. The significant decrease in hardness, not recovered during ageing (Fig. 4b), led to a considerable change in impact properties. In fact, the loss in hardness (Fig. 4b) was balanced by a substantial gain in impact toughness (Fig. 6c), with a slightly increased peak force and a tripled total absorbed energy by the material, as listed in Table 3. The fracture profiles and surfaces appeared similar to those observed in the as-built and T5 conditions, suggesting that the rapid SHT did not alter the fracture mechanisms involved. These results differ from what was reported by studies that applied the traditional T6 heat treatment (Ref 21, 26, 36) to the same alloy. Girelli et al. (Ref 21) reported impact properties for classic $T 6$ heat treatment (SHT at $540{ }^{\circ} \mathrm{C}$ for $1 \mathrm{~h}, \mathrm{AA}$ at $180^{\circ} \mathrm{C}$ for $2 \mathrm{~h}$ ). The as-built and T6 materials presented comparable values of impact properties, despite the significant change in microstructure: from as-built fine cells delimited by the eutectic network to heat-treated $\mathrm{Si}$ particles embedded in the $\alpha$-Al matrix. Besides, Girelli et al. (Ref 21) reported that heat treatment significantly reduced propagation energy from $50 \%$ down to the $30-40 \%$ range of total energy. Giovagnoli et al. (Ref 26) also investigated the impact properties for another T6 heat treatment (SHT at $520{ }^{\circ} \mathrm{C}$ for $2 \mathrm{~h}, \mathrm{AA}$ at $180^{\circ} \mathrm{C}$ for $4 \mathrm{~h}$ ), which affected the absorption of energy during impact compared to the as-built alloy. The total absorbed energy was $2.7 \mathrm{~J}$, of which only $15 \%$ by propagation. The present work showed an opposite trend, with propagation energy being $70 \%$ of total absorbed energy after the innovative T6 treatment. The propagation energy is linked to the material ductility, while the initiation energy reflects the strength of the material since it is absorbed before failure. Hence, the T6-like treatment in the present work improved the material ductility in contrast with what was reported for the conventional T6 heat treatment (Ref 21, 26).

Wang et al. (Ref 36) also reported that spheroidised $\mathrm{Si}$ particles enhanced plasticity with a limited loss in static strength after the T6-like treatment. Besides, although without clearly stated SHT duration, the authors concluded that the T6like treatment could eliminate the influence of the anisotropy typical of AMed alloys, given the various possibilities for building orientations. The influence of building orientation on the mechanical properties is a critical aspect of AMed alloys: Krishna et al. (Ref 37) assessed that a non-monodirectional scanning strategy led to almost isotropic strength; on the other hand, several studies reported different mechanical responses, depending on the building direction ( $\operatorname{Ref} 20-23,38,39)$. There was no possibility of investigating this aspect in the present work since the samples were built only in one direction along the $z$-axis. The literature reported that different impact responses can still be detected for AlSi10Mg alloys (Ref 20, 22), although minimal after heat treatment (Ref 21, 23).

Girelli et al. (Ref 21) also performed the impact test on the cast alloy after conventional T6 heat treatment (SHT at $540{ }^{\circ} \mathrm{C}$ for $1 \mathrm{~h}, \mathrm{AA}$ at $180^{\circ} \mathrm{C}$ for $2 \mathrm{~h}$ ), and the total energy absorbed was $60 \%$ initiation and $40 \%$ propagation. The ductility improvement related to the innovative T6-like treatment is also valid compared to the cast AlSi10Mg alloy.

The T5 and T6-like materials presented a significant difference in hardness, but a similar change is not evident in the impact strengths. This discrepancy between different material conditions in terms of hardness and impact strength was previously reported in the literature and ascribed to different strain-rate sensitivities (Ref 26, 40). Further in-depth microstructural investigations are required for a comprehensive description of this phenomenon.

In conclusion, the T5 deposition-simulating treatment represents a continuation of the hot-platform production, and it maintains both the hardness and the impact properties of the asbuilt material. The VD process within the temperature range of $160-180{ }^{\circ} \mathrm{C}$ similarly leads to the ageing of the material. Thus, it would substantially maintain the initial strength of the material, with a slight relief of stresses. The T6-like treatment determines a substantial loss of hardness, down to $40 \%$ after the AA at $180^{\circ} \mathrm{C}$, but a significant increase of ductility, up to three times than the asbuilt material. This result is positive in applications where impact absorption is required. Nowadays, in industrial practice, the heat treatment step is followed by the vapor deposition process (Fig. 8a), but the present work demonstrated that the artificial ageing treatment, after the innovative SHT when required, can be industrially combined the VD process, which also works as an ageing treatment (Fig. 8b). 


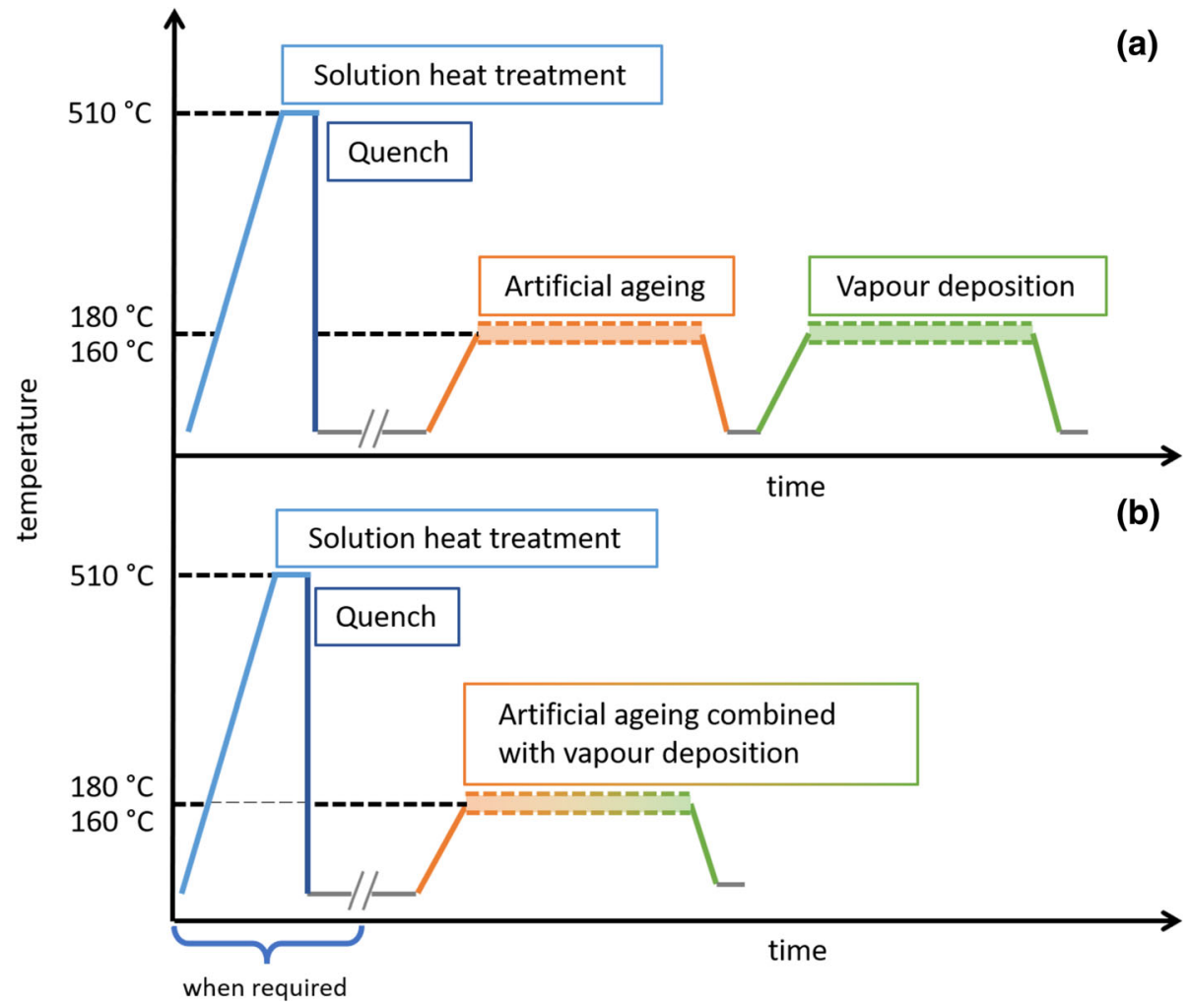

Fig. 8 Schematic representation of (a) the classical sequence of heat treatment followed by vapor deposition process, and (b) the innovative combination of ageing treatment and vapor deposition presented in this study

\section{Summary and Take-Away}

The present study aimed to describe the evolution of mechanical properties of an AlSi10Mg alloy during exposure at high temperatures. The mechanical properties were assessed as hardness and impact strength, and their evolution was linked to a microstructural variation.

The direct ageing (T5 deposition-simulating treatment) did not alter the microstructure of the as-built material, and it mirrors the stable trend of both hardness and impact properties. The artificial ageing after an innovative SHT (T6-like deposition-simulating treatment), on the other hand, determined a significant alteration of the microstructure with coarsened Si particles. The hardness significantly decreased, down to $40 \%$, but the total absorbed energy during Charpy tests was tripled.

These treatments can be easily combined with vapor deposition treatments at the same temperatures, which would provide ageing directly (T5) or after the rapid SHT (T6-like). This procedure would enable to tailor the deposition treatments for the required properties, either strength or ductility, of the final application.

Future studies will deepen the microstructure at a scale suitable to describe the various strengthening contributes during the artificial ageing of the T6-like treatment.

\section{Acknowledgments}

The present work was supported by the RIMMEL project, CUP B91F18000370009, POR FESR EMILIA ROMAGNA 2014-2020, Asse 1 - Ricerca e Innovazione. The authors gratefully acknowl- edge Dr Giovagnoli for support with the AM literature, Mr Souati and Mr Di Egidio for part of the experimental work.

\section{Funding}

Open access funding provided by Jönköping University.

\section{Conflict of interest}

The authors report no declarations of interest.

\section{Open Access}

This article is licensed under a Creative Commons Attribution 4.0 International License, which permits use, sharing, adaptation, distribution and reproduction in any medium or format, as long as you give appropriate credit to the original author(s) and the source, provide a link to the Creative Commons licence, and indicate if changes were made. The images or other third party material in this article are included in the article's Creative Commons licence, unless indicated otherwise in a credit line to the material. If material is not included in the article's Creative Commons licence and your intended use is not permitted by statutory regulation or exceeds the permitted use, you will need to obtain permission directly from the copyright holder. To view a copy of this licence, visit http://creativecommons.org/licenses/by/4.0/.

\section{References}

1. J. Wu, X.Q. Wang, W. Wang, M.M. Attallah and M.H. Loretto, Microstructure and Strength of Selectively Laser Melted AlSi10Mg, Acta Mater., 2016, 117, p 311-320 
2. L. Tonelli, E. Liverani, A. Morri and L. Ceschini, Role of Direct Aging and Solution Treatment on Hardness, Microstructure and Residual Stress of the A357 (AlSi7Mg0.6) Alloy Produced by Powder Bed Fusion, Metall. Mater. Trans. B Process Metall. Mater. Process. Sci., $2021 \mathrm{https} / / /$ doi.org/10.1007/s11663-021-02179-6

3. L. Tonelli, E. Liverani, G. Valli, A. Fortunato and L. Ceschini, Effects of Powders and Process Parameters on Density and Hardness of A357 Aluminum Alloy Fabricated by Selective Laser Melting, Int. J. Adv. Manuf. Technol., 2020, 106(1-2), p 371-383

4. K.G. Prashanth, S. Scudino, H.J. Klauss, K.B. Surreddi, L. Löber, Z. Wang, A.K. Chaubey, U. Kühn and J. Eckert, Microstructure and Mechanical Properties of Al-12Si Produced by Selective Laser Melting: Effect of Heat Treatment, Mater. Sci. Eng. A, 2014, 590, p 153-160. https://doi.org/10.1016/j.msea.2013.10.023

5. N.T. Aboulkhair, I. Maskery, C. Tuck, I. Ashcroft and N.M. Everitt, The Microstructure and Mechanical Properties of Selectively Laser Melted AlSi10Mg: The Effect of a Conventional T6-like Heat Treatment, Mater. Sci. Eng. A, 2016, 667, p 139-146. https://doi.org/ 10.1016/j.msea.2016.04.092

6. E. Brandl, U. Heckenberger, V. Holzinger and D. Buchbinder, Additive Manufactured AlSi10Mg Samples Using Selective Laser Melting (SLM): Microstructure, High Cycle Fatigue, and Fracture Behavior, Mater. Des., 2012, 34, p 159-169. https://doi.org/10.1016/j.matdes.20 11.07.067

7. E. Cerri, E. Ghio and G. Bolelli, Effect of the Distance from Build Platform and Post-Heat Treatment of AlSi10Mg Alloy Manufactured by Single- and Multi-Laser Selective Laser Melting, J. Mater. Eng. Perform., 2021 https://doi.org/10.1007/s11665-021-05577-8

8. P. Yang, M.A. Rodriguez, L.A. Deibler, B.H. Jared, J. Griego, A. Kilgo, A. Allen and D.K. Stefan, Effect of Thermal Annealing on Microstructure Evolution and Mechanical Behavior of an Additive Manufactured AlSi10Mg Part, J. Mater. Res., 2018, 33(12), p 17011712

9. J. Fiocchi, A. Tuissi, P. Bassani and C.A. Biffi, Low Temperature Annealing Dedicated to AlSi10Mg Selective Laser Melting Products, $J$. Alloys Compd., 2017, 695, p 3402-3409

10. W. Li, S. Li, J. Liu, A. Zhang, Y. Zhou, Q. Wei, C. Yan and Y. Shi, Effect of Heat Treatment on AlSi10Mg Alloy Fabricated by Selective Laser Melting: Microstructure Evolution, Mechanical Properties and Fracture Mechanism, Mater. Sci. Eng. A, 2016, 663, p 116-125. h ttps://doi.org/10.1016/j.msea.2016.03.088

11. M. Fousová, D. Dvorský, A. Michalcová and D. Vojtěch, Changes in the Microstructure and Mechanical Properties of Additively Manufactured AlSi10Mg Alloy after Exposure to Elevated Temperatures, Mater. Charact., 2018, 137(January), p 119-126

12. N. Takata, H. Kodaira, K. Sekizawa, A. Suzuki and M. Kobashi, Change in Microstructure of Selectively Laser Melted AlSi10Mg Alloy with Heat Treatments, Mater. Sci. Eng. A, 2017, 704(May), p 218-228. https://doi.org/10.1016/j.msea.2017.08.029

13. A.H. Maamoun, M. Elbestawi, G.K. Dosbaeva and S.C. Veldhuis, Thermal Post-Processing of AlSi10Mg Parts Produced by Selective Laser Melting Using Recycled Powder, Addit. Manuf., 2018, 21(February), p 234-247. https://doi.org/10.1016/j.addma.2018.03.014

14. L. Zhou, A. Mehta, E. Schulz, B. McWilliams, K. Cho and Y. Sohn, Microstructure, Precipitates and Hardness of Selectively Laser Melted AlSi10Mg Alloy before and after Heat Treatment, Mater. Charact., 2018, 143(April), p 5-17. https://doi.org/10.1016/j.matchar.2018.04.0 22

15. R. Casati, M.H. Nasab, M. Coduri, V. Tirelli and M. Vedani, Effects of Platform Pre-Heating and Thermal-Treatment Strategies on Properties of AlSi10Mg Alloy Processed by Selective Laser Melting, Metals (Basel), 2018, 8(11), p 954

16. Z. Fan, Y. Wang, Y. Zhang, T. Qin, X.R. Zhou, G.E. Thompson, T. Pennycook and T. Hashimoto, Grain Refining Mechanism in the Al/AlTi-B System, Acta Mater, 2015, 84, p 292-304. https://doi.org/10. 1016/j.actamat.2014.10.055

17. P. Van Cauwenbergh, A. Beckers, L. Thijs, B. Van Hooreweder, and K. Vanmeensel, Heat Treatment Optimization via Thermo-Physical Characterisation of AlSi7Mg and AlSil0Mg Manufactured by Laser Powder Bed Fusion (LPBF), Euro PM2018, 2018, (October), p 1-7

18. J. Fiocchi, C.A. Biffi, C. Colombo, L.M. Vergani and A. Tuissi, Ad Hoc Heat Treatments for Selective Laser Melted Alsi10mg Alloy Aimed at Stress-Relieving and Enhancing Mechanical Performances, Jom, 2020, 72(3), p 1118-1127. https://doi.org/10.1007/s11837-01903973-z
19. "PVD AND PaCVD COATINGS," (Cellatica (BS), Italy), 2020, www. sts-group.it

20. K. Kempen, L. Thijs, J. Van Humbeeck and J.P. Kruth, Mechanical Properties of AlSi10Mg Produced by Selective Laser Melting, Phys. Procedia, 2012, 39, p 439-446. https://doi.org/10.1016/j.phpro.2012. 10.059

21. L. Girelli, M. Giovagnoli, M. Tocci, A. Pola, A. Fortini, M. Merlin and G.M. La Vecchia, Evaluation of the Impact Behaviour of AlSi10Mg Alloy Produced Using Laser Additive Manufacturing, Mater. Sci. Eng. A, 2019, 748, p 38-51. https://doi.org/10.1016/j.msea.2019.01.078

22. C.S. Rakesh, N. Priyanka, R. Jayaganthan and N.J. Vasa, Effect of Build Atmosphere on the Mechanical Properties of AlSi10Mg Produced by Selective Laser Melting, Mater. Today Proc., 2018, 5(9), p 17231-17238. https://doi.org/10.1016/j.matpr.2018.04.133

23. M. Giovagnoli, On the Process-Microstructure-Properties Relationship of a Laser Additively Manufactured AlSi10Mg Alloy. University of Ferrara, 2021

24. I. Rosenthal, R. Shneck and A. Stern, Heat Treatment Effect on the Mechanical Properties and Fracture Mechanism in AlSi10Mg Fabricated by Additive Manufacturing Selective Laser Melting Process, Mater. Sci. Eng. A, 2018, 729, p 310-322. https://doi.org/10.1016/j. msea.2018.05.074

25. S. Bagherifard, N. Beretta, S. Monti, M. Riccio, M. Bandini and M. Guagliano, On the Fatigue Strength Enhancement of Additive Manufactured A1Si10Mg Parts by Mechanical and Thermal Post-Processing, Mater. Des., 2018, 145, p 28-41. https://doi.org/10.1016/j.matdes. 2018.02.055

26. M. Giovagnoli, M. Tocci, A. Fortini, M. Merlin, M. Ferroni, A. Migliori and A. Pola, Effect of Different Heat-Treatment Routes on the Impact Properties of an Additively Manufactured AlSi10Mg Alloy, Mater. Sci. Eng. A, 2021, 802, 140671. https://doi.org/10.1016/j.msea. 2020.140671

27. L. Girelli, M. Tocci, M. Gelfi and A. Pola, Study of Heat Treatment Parameters for Additively Manufactured AlSi10Mg in Comparison with Corresponding Cast Alloy, Mater. Sci. Eng. A, 2019, 739, p 317-328

28. L. Thijs, K. Kempen, J.P. Kruth and J. Van Humbeeck, Fine-Structured Aluminium Products with Controllable Texture by Selective Laser Melting of Pre-Alloyed AlSi10Mg Powder, Acta Mater, 2013, 61(5), p 1809-1819. https://doi.org/10.1016/j.actamat.2012.11.052

29. T. Maeshima and K. Oh-ishi, Solute Clustering and Supersaturated Solid Solution of AlSi10Mg Alloy Fabricated by Selective Laser Melting, Heliyon, 2019, 5(2), p e01186. https://doi.org/10.1016/j.he liyon.2019.e01186

30. R. Casati and M. Vedani, Aging Response of an A357 Al Alloy Processed by Selective Laser Melting, Adv. Eng. Mater., 2019, 21(4), p $1-7$

31. A. Aversa, M. Lorusso, F. Trevisan, E.P. Ambrosio, F. Calignano, D. Manfredi, S. Biamino, P. Fino, M. Lombardi and M. Pavese, Effect of Process and Post-Process Conditions on the Mechanical Properties of an A357 Alloy Produced via Laser Powder Bed Fusion, Metals (Basel), 2017, 7(2), p 1-9

32. W.-C. Chen, S.-L. Lee and A.-H. Tan, Effect of Pre-Ageing on the Precipitation Behaviors and Mechanical Properties of Al-7Si-Mg Alloys, J. Mater. Sci. Chem. Eng., 2018, 06(03), p 55-67

33. G.A. Edwards, K. Stiller, G.L. Dunlop and M.J. Couper, The Precipitation Sequence in Al-Mg-Si Alloys, Acta Mater,, 1998, 46(11), p 3893-3904

34. S. Marola, D. Gianoglio, F. Bosio, A. Aversa, M. Lorusso, D. Manfredi, M. Lombardi and L. Battezzati, Alloying AlSi10Mg and $\mathrm{Cu}$ Powders in Laser Single Scan Tracks, Melt Spinning, and Laser Powder Bed Fusion, J. Alloys Compd., 2020, 821, 153538. https://doi. org/10.1016/j.jallcom.2019.153538

35. S. Marola, D. Manfredi, G. Fiore, M.G. Poletti, M. Lombardi, P. Fino and L. Battezzati, A Comparison of Selective Laser Melting with Bulk Rapid Solidification of AlSi10Mg Alloy, J. Alloys Compd., 2018, 742, p 271-279. https://doi.org/10.1016/j.jallcom.2018.01.309

36. L.F. Wang, J. Sun, X.L. Yu, Y. Shi, X.G. Zhu, L.Y. Cheng, H.H. Liang, B. Yan and L.J. Guo, Enhancement in Mechanical Properties of Selectively Laser-Melted AlSi10Mg Aluminum Alloys by T6-like Heat Treatment, Mater. Sci. Eng. A, 2018, 734(August), p 299-310

37. M. Krishnan, E. Atzeni, R. Canali, F. Calignano, D. Manfredi, E.P. Ambrosio and L. Iuliano, On the Effect of Process Parameters on Properties of AlSi10Mg Parts Produced by DMLS, Rapid Prototyp. J., 2014, 20(6), p 449-458 
38. G. Qian, Z. Jian, Y. Qian, X. Pan, X. Ma and Y. Hong, Very-HighCycle Fatigue Behavior of AlSi10Mg Manufactured by Selective Laser Melting: Effect of Build Orientation and Mean Stress, Int. J. Fatigue, 2019, 2020(138), 105696. https://doi.org/10.1016/j.ijfatigue.2020.105 696

39. G. Qian, Y. Li, D.S. Paolino, A. Tridello, F. Berto and Y. Hong, VeryHigh-Cycle Fatigue Behavior of Ti-6Al-4V Manufactured by Selective Laser Melting: Effect of Build Orientation, Int. J. Fatigue, 2020, 136(March), p 105628. https://doi.org/10.1016/j.ijfatigue.2020.105628
40. J.C.F. Millett, Modifications of the Response of Materials to Shock Loading by Age Hardening, Metall. Mater. Trans. A Phys. Metall. Mater. Sci., 2015, 46(10), p 4506-4517. https://doi.org/10.1007/s116 61-014-2571-z

Publisher's Note Springer Nature remains neutral with regard to jurisdictional claims in published maps and institutional affiliations. 